\title{
ACADEMIC INTEGRITY, AXIOLOGY AND BUSINESS ETHICS PEDAGOGY
}

\author{
Caroline Burns
}

\begin{abstract}
This purpose of this paper is to outline how values theory can be incorporated into a business ethics curriculum and how academic integrity can be recruited in doing so. The paper presents a pedagogical approach that allows students to reflect on their values, articulate their values stances, and learn how values influence both ethical and unethical behavior. The paper also demonstrates how academic dishonesty is an effective means by which to teach students the pathway from values, to attitudes, to behavior, while also teaching students the long-term ramifications of behaving unethically during their time spent in higher education.
\end{abstract}

Key words: Academic Integrity, Academic Dishonesty, Business Ethics Pedagogy, Values, Axiology

\section{Introduction}

Business ethics courses are integral to business education as they contribute to students' moral development and ultimately inform ethical behaviors post-graduation (Crossan et al., 2013). While these courses do not make students ethical, they are a starting point in endeavoring to make ethics more commonplace in students' decisions. In his widely referenced article on business ethics Goshal wrote, "When managers, including CEOs, justify their actions by pleading powerlessness in the face of external forces... When they claim that competition or capital markets are relentless in their demands and that individual companies and managers have no scope for choices, it is on the strength of the false premise of determinism that they free themselves from any sense of moral or ethical responsibility for their actions" (p. 79, 2005). This determinism is a barrier to being ethical in business, but more germane to this paper, it is a hurdle to teaching business ethics. Additionally, not only do many students believe that businesses cannot be both profitable and ethical, but their personal goals might discourage them from pursuing both ends. Giacalone and Promislo (2013) for example argue that many students in business ethics courses arrive at higher education with "baggage" in the form of a worldview not congruent with a business ethics course. They posit, "this baggage impedes the dissemination and acceptance of ethics concepts and renders students ethically broken when entering our classrooms" because of their biases toward materialism, power, and winning at any cost (p. 87). Taken together, these barriers place a tremendous burden on business ethics instructors to develop an effective curriculum and associated pedagogy.

This paper and the pedagogy it describes heeds the call from May et al. (2014), in their work on the interaction between business ethics courses moral efficacy, moral meaningfulness, and moral courage to develop instructional methods that allow students to link ethics to their values, and then to their careers. Kupperman (1996) notes that reflecting on values can influence behavior arguing, "Lived experience does 
very often affect people's values. But so do thought experiments, imaginative creations of what it would be like to live through certain things" (1996, p. 124). Healso rightly acknowledges that it is not obvious how best to inspire students to contemplate values. To this end, this paper documents a pedagogical approach that allows students to engage in such contemplation that is designed to (a) develop students' knowledge of values theory, (b) teach students how to articulate their values stances, and (c) examine how their values influence attitudes and behaviors. Another important purpose of this paper is to demonstrate how academic dishonesty can be recruited to teach students the pathway from values, to attitudes, to behavior (both ethical and unethical), while concurrently unearthing the potential values and attitudes antecedents related to academic dishonesty and academic integrity based behaviors.

The paper first outlines why innovation around business ethics pedagogy is warranted. It then proceeds to detail why academic integrity used as a case study is salient to teaching business ethics. The content and pedagogy are then described, and anecdotal observations following on from the module are provided.

\section{Supplemental Business Ethics Pedagogy}

The common approach to teaching business ethics is to begin by teaching theories such as utilitarianism, deontology, and virtue ethics so that students can develop their moral reasoning skills. Instructors then build upon this by working with students to consider ethical dilemmas and/or case studies using these theories. While widely used, these pedagogical approaches have their critics. Traditional undergraduate students often have little to no work experience and therefore find it difficult to connect to business ethics cases or dilemmas. Moreover, Neesham and Gu (2015) argue that this approach does not engage the affective side of students' characters. Case studies, they write, do not teach business ethics effectively because students are not personally involved with the cases under analysis and consequently there is little to tie a case to a student's life or future. As Orms (2016) summarizes, evidence suggests that the pedagogy tools commonly used may be helpful but are insufficient in creating ethical decision-makers; they are better than nothing she argues, but nonetheless inadequate. This paper is not intended to add to this critique, but rather to highlight an approach that supplements, not supplants, the common approach while also drawing attention to the problem of academic dishonesty among students.

\section{Why Values?}

According to Sims and Brinkmann (2003), business ethics courses must focus on moral courage, moral issues, moral judgment, handling moral issues, and moral sensitivity but they should also help students develop self-knowledge about their values and their motivation to address such moral issues. Jagger and Volkman (2014) also argue that ethics courses must require that students be in touch with their values. Finally, Neesham and $\mathrm{Gu}$ (2015) argue that an effective way to bridge business ethics education and ethical behavior is to hone in on students' morality through a reflection on values. The pedagogy described below has been developed in light of the efficacy of values based pedagogy in teaching business ethics. 
Business courses that ignore the affective aspect of decision-making run the risk of improving students' ability to reason decisions at the risk of subordinating emotions, personality, power disparities, values, and so forth. Ethics incorporating affect is more meaningful in influencing ethical behavior than ethics by reasoning (Cushman et al., 2006), thus increasing students' emotional attachment to the material would make the course more effective. Incorporating values into a business ethics course improves how students connect with the course content but finding additional means to strengthen the affective link between students and content is warranted. Academic misconduct as an example of unethical behavior is much more relevant to students' lives than business cases on subjects like corporate corruption or price gouging for instance and ties students personally to an ethics issue. As such, efforts must be made by instructors to find salient examples of unethical behavior with which to discuss ethics with students. In the case of the business ethics pedagogy discussed herein, academic misconduct was chosen.

\section{Why Academic Integrity?}

Given there are other unethical behaviors salient to students, why academic dishonesty? There is no disputing that some business students have little concern for academic integrity, though whether business students cheat more than other students is unclear, due to conflicting findings (see Klein et al., 2007; Lang, 2013; McCabe et al., 2006). The literature highlights a myriad of ways in which academic dishonesty segues to misconduct in other aspects of students' lives. For example, high school students who cheat are very likely to go on to lie to their spouses, their customers, and their employers. In addition, they are more likely to be dishonest than students who do not cheat on an expense report or when filing an insurance claim (Josephson Institute, 2009). Moreover, Lawson (2004) found that students who cheated at college were more tolerant of unethical behavior in business. Sims (1993) found that graduate business students who had behaved dishonestly in graduate school went on to behave dishonestly at work. Later, Nonis and Swift (2001) established a link between cheating behavior among both undergraduate and graduate business students and unethical behavior at work. Most alarming, Teixeira (2013) uncovered that those countries with high levels of cheating by economics and business students during college experience more corruption. She argued that unethical behavior by college students (in this case, cheating on tests) carries over into their professional lives in the years after they joined the workforce. Overall, students' unethical behavior is one of the most reliable predictors of future work-related unethical behavior, and there is a high degree of similarity in the justification for being unethical in both contexts (Carpenter, et al., 2010). It follows that diminishing academic misconduct by not allowing it to become the students' norm, might decrease students' likelihood of behaving unethically once they graduate. Indeed, reducing unethical behavior at college can lead to an improvement in ethics in organizations (Granitz \& Loewy, 2007). The pedagogy presented was designed to support ends. 


\section{The Values Module}

Outlined in the following section is a pedagogy that makes up a values module I use to teach values theory to undergraduate business ethics students and a related assessment. The values module (pedagogy) forms the basis for a term paper (assessment), written over the course of the semester. The paper incorporates a detailed articulation of students' values, the role their values play in preference toward one ethical framework over another, their attitude towards the role of business in society, their concern about particular ethical issues in their chosen career, and what they might do if faced with the ethical issues that most concern them. The discussion below describes the process before students write their paper. The module consists of two weeks of in-class work and homework and comprises the following elements:

A. Calculation of students' values using the Schwartz Value Survey.

B. Completion of a survey on academic integrity.

C. Lectures on values theory and the link between values, attitudes, and behavior.

D. Interpretation of students' values data.

E. Determining the relationship between each student's values and their attitudes toward academic integrity and academic misconduct.

F. Lecture and discussion on the links between college and professional behavior.

\section{Element A}

Before students learn about values, they complete the Schwartz Values Survey (SVS) (see Appendix A for the survey) so as not to increase their inclination towards socially desirable responses. The SVS is a widely used survey instrument in values research to collect data on the personal values of survey participants. The SVS consists of 57 values, incorporated into two inventories of values: List I and List II. Students rate these values as guiding principles in their lives using a 9-point Likert scale. The scale ranges from -1 , opposed to my values, to 7 , of supreme importance. From List I, students select the most important of the 30 values and the least important of the 30 values to anchor subsequent choices on List I. They then repeat this process with List II. Having done this, students insert their numbers into an excel spreadsheet that categorizes the ratings on the 57 individual values into 10 value types that rank from least to most important. Students are not required to share details with anyone. These numbers form the basis of the students' articulations of their values that come later.

\section{Element B}

The next step is for students to complete a short survey consisting of questions based on those used on the McCabe Academic Integrity Student Survey, though they are not identical. Students are not required to share their responses with anyone, but rather use the survey responses later in the module in conjunction with their values responses. I decided that if academic integrity was to be the method with which I were to teach students the link between values and behavior we needed a common, 
strong vocabulary. Flushing students' thoughts on academic misconduct through an academic integrity survey is an effective way to develop such a vocabulary.

\section{Element C}

Values while a commonly spoken of construct are often ill defined and misinterpreted when used, therefore it is important to anchor the knowledge acquisition goals I have for this model to academically determined definitions and theory. What follows is a brief description of the what the students learn about during the module.

Schwartz and Bilsky explain that values are "concepts or beliefs, pertaining to desirable end states, which transcend specific situations, guide selection or evaluation of behavior and events, and are ordered by relative importance" (1987, p. 551.) People organize values in a hierarchy, which determines the value that prevails in any given situation (Rokeach, 1973). They are assessments of abstract concepts and they are used to evaluate others, the actions of others, attitudes, things, and the self (Maio et al., 1996). Drob (2016) correctly states that values are in many ways separate from morals, ethics, and virtues; rather, they are guiding principles in a person's life. In sum, values are sources of motivation in peoples' lives. So, for instance, one person might be more motivated by equality than wealth, whereas another might be more motivated by wealth than equality. From a values perspective, neither person is more or less ethical, or more or less moral. While values are important to understanding behavior (Alwin \& Krosnick, 1985), the role of attitudes cannot be forgotten as attitudes act as the mediator in the value-behavior relationship (Homer \& Kahle, 1988; McCarty \& Shrum, 1994); attitudes are the antecedents to behavior, and values are the antecedents to attitudes. In as much as values reflect individuals "preferred states of being or feelings", behavior reflects their "preferred ways of behaving" (McGregor, 2000, p. 94). It is this relationship between preferred states of beings (motivations) and behavior that students must become familiar with to understand why people differ in their behavior and why some people behave unethically when others do not.

The Schwartz Theory of Human Values is the theory used in this module to teach students. The theory and the SVS are widely used for research on the values positions of groups around the world and in many contexts. Using the SVS, Schwartz (1992) identified 57 individual values present in societies across the globe (see Table 1). He also grouped these values into 10 value types based on their common motivational goal (See Table 2): Power, Achievement, Hedonism, Stimulation, Self-direction, Universalism, Benevolence, Conformity, Tradition, and Security (see Table 1). These 10 value types are mapped out on a circumplex (see Figure 1.) Each wedge of the circumplex represents one of the ten value types. The location of each wedge is meaningful, as it indicates the relationship between the values each wedge represents, which then influence subsequent behavior. This second aspect of Schwartz's work, the relationships between value types, speaks to the fact that multiple value types may motivate a person at the same time, especially when they share similar underlying motivational goals (see Table 3). Moreover, behavior consistent with one value type would conflict with that consistent with another value type because the two value types do not share a motivational goal (see Table 3). For example, the set of individual 
values in the Power type (social power, authority, wealth, preserving my public image, social recognition) satisfies people's motivation concerning "social status and prestige, control, or dominance over people and resources" (Schwartz, 1994, p. 22). For instance, behavior based on Power does not conflict with behavior driven by Achievement, which consists of the individual values: successful, capable, ambitious, influential, intelligent. This is the case because Achievement relates to the need for "personal success through demonstrating competence according to social standards" (p. 22). The shared motivational goal between Power and Achievement is "Social superiority and esteem" (p. 24), thus the congruency in potentially related attitudes and behavior. ${ }^{1}$ Once this theory has been introduced we discuss the role of values in behavior students might have undertaken already such as choosing a degree, social justice activity, selecting pastimes, consumption patterns, and so forth.

\section{Element D}

Having completed the SVS as well as attending the theory lectures, students begin the process of examining their values stance. They add their values ranks established at the start of the module to the circumplex to see how their ranks map out and then use the motivational definitions from Tables 1-3 to write their first draft of their values stances. They might start for example by describing themselves as being most motivated by Power and least motivated by Universalism and so forth. Once completed, I provide written feedback on their interpretations before we begin the discussion phase. During group discussions, student volunteers share their findings. (If there are not enough volunteers, we discuss my values ranks.) By doing so students hear about their peers' motivations (values hierarchies), which allows students to see how they differ from their peers and friends. They also reflect upon and describe how they feel about these differences. Without exception, every semester students describe how they are surprised at what the numbers reveal. For example, many students believe they are broadminded and are motivated by social justice, but comparing themselves to their peers and the literature, they might find others might be more so inclined. Students learn about the averages from one of the module's assigned readings. Alternatively, they might find they are more Power or Achievement oriented than the average. Those who considered themselves motivated by Self-Direction values might learn for example that Tradition and Conformity have a greater influence on them than they imagined. This always creates an energetic and fun discussion.

\section{Element E}

To learn how values affect behaviors we then begin by practicing with how students' values interact with their self-reported numbers on academic misconduct. Students first have to determine how their values influence their attitudes towards academic misconduct guided by their response to the survey taken at the start of the class and then the range of associated behaviors. Students share their insights with me individually and I provide some examples to the class for discussion to hide the

\footnotetext{
${ }^{1}$ For a detailed explanation, refer to Schwartz (1992; 1994).
} 
identity of the students proposing a particular value, attitude, behavior link. Through this discussion, students learn that prioritising one value over another might deter cheating behavior, as it would give rise to a negative attitude towards cheating on a test for example, and thus deter the student from cheating (the attitude-behavior link.) Conversely, another value preference might lead to cheating behavior as it would give rise to a positive attitude towards cheating on a test, and thus encourage a student to cheat if the opportunity arises. It is during this discussion that an in-depth understanding of the value, attitude, and behavior relationship starts to emerge.

\section{Element F}

Once I am confident that students have a good grasp on how values work I present evidence from the literature regarding the correlation between unethical behavior in college (academic misconduct) and subsequent unethical behavior at work. At this point, we are ready to move on to discussing how their values, in general, might influence their professional behavior and the behavior of their future work colleagues.

Finally, as noted above one of the main assignments for this course is a semesterlong project that requires students to write about their values and how they influence a range of constructs. Students are not required to include details about academic misconduct; rather, they reflect on how values affect other areas of their lives currently and potentially when they move on to the workplace having practiced this reflection using academic misconduct.

\section{Anecdotal Observations}

Even though students use the SVS to create their values profile and the SVS is commonly used in values research, I do not collect students' data for research purposes. This paper describes a pedagogy only. That said, there are anecdotal indicators from approximately 140 students concerning how students' values interact with their views on academic misconduct.

Chapman et al. (2004) found that students were inclined to engage in academic misconduct to help a friend. Therefore, it seemed intuitive that Benevolence (concern about the in-group) would correlate with helping a friend with an assignment or on a test. This did indeed appear to be the case during the discussions. Conversely, a student who ranked Universalism highest told her peers that she would not involve herself in any type of academic misconduct as doing so is unfair to everyone; Universalism's underlying motivation is "Understanding, appreciation, tolerance, and protection, for the welfare of all people and for nature" (Schwartz, 1994, p. 22). This link becomes clearer when one considers the individual values that make up Universalism: broadminded, wisdom, social justice, equality, a world at peace, a world of beauty, unity with nature, protecting the environment. This is likely related to her motivations with respect to fairness for everyone or put another way; prioritization of the in-group among high Benevolence students versus no such distinction made by students high in Universalism (as they would not hold the in-group in higher esteem than the outgroup.) 
It emerged that students high in Conformity were influenced by what their peers think and do around the issue of academic dishonesty. This is unsurprising as the motivational goal for Conformity is "Restraint of actions, inclinations, and impulses likely to upset or harm others and violate social expectations or norms" (Schwartz, 1994, p. 22). In addition, the literature indicates that this is no coincidence. Studies show that knowing others cheat increases a person's likelihood of cheating (Rettinger \& Kramer, 2009). Therefore, if academic misconduct is normed within a group, then those students who are driven to adhere to norms might be more inclined to follow the lead of their friends who engage in academic misconduct.

Some students who reported that they were highly motivated by Achievement appeared to view academic misconduct as inevitable, given the pressure to obtain a high grade point average (GPA) to secure a job or a place at graduate school. This was foreseeable given that Achievement's motivational goal is "Personal success through demonstrating competence according to social standards" (Schwartz, 1994, p. 22). This too accords with the literature, such as the finding that students believe cheating gives them a competitive edge (Drye et al., 2018). Also, Stuber-McEwen et al. (2009) determined that students who worried about their grades are likely to participate in behaviors related to academic dishonesty, but they also found students worried about scholarships do so too. Relatedly, because Achievement and Power share a motivational goal, "social superiority and esteem."

A student also explained that his Power rank and his concern about his public image meant that he would not jeopardize his image by being unethical. Power's underlying motivation is "Social status and prestige, control or dominance over people and resources" (Schwartz, 1994, p. 22.).

One student, who ranked Stimulation high, disclosed that she is likely to see unethical activities at work and college and she could not guarantee she would refrain from engaging in these if doing so would do little harm but result in a lot of benefits. This reflects a pattern among students high on Openness to Change. Students high on Stimulation and Hedonism seemed less inclined to view academic misconduct negatively. Time pressures seemed to be a factor for the high Hedonism students and benefits outweighing the risks appeared to be a popular justification with students who ranked Stimulation values high. Schwartz (1992) suggests that people learn values through group interaction and individual experiences, which suggests that students who have grown up to be motivated by Self-Direction might be less likely to cheat when everyone else around them is cheating, but this did not seem to be the case in the details that emerged from this project.

\section{Conclusion}

During this values module, students learn that behaviors are not as random as they might think and that the potential for unethical behavior lies within every person. They also learn a little cheating here and there can lead to other forms of unethical behavior in their careers. The subordination of ethics to the win-at-all-costs perspective described above simultaneously challenges business ethics professors and educational institutions. 
An important reason to incorporate academic integrity into the curriculum is the far-reaching impact of academic misconduct. Despite my discussing the honor code, deterrents, plagiarism checkers like Turnitin, and so forth at the beginning of every semester, this unfortunately does not deter everyone from cheating. As a result of adding academic dishonesty as the ethical issue to this module, my goal is that when students hear their class peers talk about the lack of fairness and the harm it can cause to other students, the institution, future employers, and coworkers it will raise students' respect for academic integrity.

It is worth mentioning the unintended consequence to rolling academic integrity into the curriculum is that it might teach students how to rationalize academic misconduct. A student will now know to claim that her need for security made her cheat! That would probably be more socially acceptable than claiming she had to do it because she is highly motivated by a high GPA.

By the time students leave higher education, there is a high chance that they will have cheated at least once (Drye et al., 2018). Additionally, the prevalence of unethical behavior persisting across time reinforces the danger of ignoring student cheating (Teixeira, 2013). Research shows that the best way to affect students' attitudes and behavior with respect to academic integrity is to take a semester-long approach (Shaftel \& Shaftel, 2005), which is what this values module linked to the term paper does. Ultimately, connecting academic integrity to professional ethics increases the chances that students will adopt the ethical standards required of their professions (Atkinson, Nau, \& Symons, 2016).

\section{References}

Alwin, D. F., \& Krosnick, J. A. (1985). The measurement of values in surveys: A comparison of ratings and rankings. Public Opinion Quarterly, 49(4), 535-552.

Atkinson, D., Zaung NAU, S., \& Symons, C. (2016). Ten years in the academic integrity trenches: Experiences and Issues. Journal of Information Systems Education, 27(3), 197-207.

CARPenter, D. D., Harding, T. S., \& Finelli, C. J. (2010). Using research to identify academic dishonesty deterrents among engineering undergraduates. International Journal of Engineering Education, 26(5), $1156-1165$.

Chapman, K. J., Davis, R., Toy, D., \& Wright, L. (2004). Academic integrity in the business school environment: I'll get by with a little help from my friends. Journal of Marketing Education, 26(3), 236-249.

Crossan, M., Mazutis, D., Seijts, G., \& Gandz, J. (2013). Developing leadership character in business programs. Academy of Management Learning E Education, 12(2), 285-305.

Cushman, F. Young, L., \& Hauser, M. (2006). The role of conscious reasoning and intuition in moral judgment: Testing three principles of harm. Psychological Science, 17(12), 1082-1089.

Drob, S. L. (2016). An axiological model of the relationship between consciousness and values. New Ideas in Psychology, 43, 57-63.

Drye, S. L., Lomo-DAVID, E., SNyder, L. G. (2018). Is cheating normal deviance? At what level does deviance become normal if deviant? Southern Journal of Business and Ethics, 10, 71-84.

Giacalone R. A., \& Promislo, M. D. (2013). Broken when entering: The stigmatization of goodness and business ethics education. Academy of Management Learning E Education, 12(1), 86-101. 
GranitZ, N., \& LoEwY, D. (2007). Applying ethical theories: Interpreting and responding to student plagiarism. Journal of Business Ethics, 72, 293-306.

Hartman, E. M. (2016). Can we teach character? An Aristotelian Answer. Academy of Management Learning E Education, 5(1), 68-81.

Homer, P. M., \& Kahle, L. R. (1988). A structural equation test of the value-attitude-behavior hierarchy. Journal of Personality and Social Psychology, 54(4), 638-646.

JagGer, S., \& Volkman, R. (2014). Helping students to see for themselves that ethics matters. International Journal of Management Education, 12(2), 177-185.

JosEphSON INSTITUTE OF EThics (2009). Josephson institute's report card on American youth: There's a hole in our moral ozone and it's getting bigger Youth. Retrieved from http://www.josephsoninstitute.org/reportcard/index.html.

Klein, H. A., Levenburg, N. M., McKendall, M., \& Mothersell, W. (2007). Cheating during the college years: How do business school students compare? Journal of Business Ethics, 72(2), 197-206.

Kupperman, J. J. (1996). Axiological Realism. Philosophy, 71(276), 185-203.

LANG, J. M. (2013). Cheating lessons: Learning from academic dishonesty. Cambridge, Massachusetts: Harvard University Press.

LAWSON, R. A. (2004). Is classroom cheating related to business school students' propensity to cheat in the "real world"? Journal of Business Ethics, 49(2), 189-199.

Maio, G. R., Roese, N. J., Seligman, C., \& Katz, A. (1996). Ranking, ratings and the measurement of values: Evidence for the superior validity of ratings. Basic and Applied Social Psychology, 18(2), 171-181.

May, D. R., Luth, M. T., \& Schwoerer, C. E. (2014). The influence of business ethics education on moral efficacy, moral meaningfulness, and moral courage: A quasi-experimental study. Journal of Business Ethics, 124(1), 67-80.

McCabe, D. L., Butterfield, K. D., \& Trevino, L. K. (2006). Academic dishonesty in graduate business programs: Prevalence, causes, and proposed action. Academy of Management Learning and Education, 5(3), 294-305

McCarty, J. A., \& Shrum, L. J. (1993). The role of personal values and demographics in predicting television viewing behavior: Implications for theory and application. Journal of Advertising, 22(4), 77-101.

McGregor, S. L. T. (200o). Using social and consumer values to predict marketplace behaviour: questions of congruency. Journal of Consumer Studies \& Home Economics, 24(2), 94-103.

Neesham, C., \& GU, J. (2015). Strengthening moral judgment: A moral identity-based leverage strategy in business ethics education. Journal of Business Ethics, 131(3), 527-534.

Nonis, S., \& SwIFT, C. (2001). An examination of the relation between academic dishonesty and workplace dishonesty: A multi-campus investigation. Journal of Education for Business, 77(2), 69-77.

Orms, C. M. (2016). Developing the personal ethics code: A key element of an effective business ethics course. Business Education Innovation Journal, 8(2), 51-58.

Rettinger, D., \& Kramer, Y. (2009). Situational and Personal Causes of Student Cheating. Research in Higher Education, 50, 293-313.

Rокеасн, M. (1973). The nature of human values. New York: Free Press.

SchWARTz, S. H. (1994). Are there universal aspects in the structure and contents of human values. Journal of Social Issues, 50(4), 19-45.

SCHWARTz, S. H. (1992). Universals in the content structure and content of values: theoretical advances and empirical tests in 20 countries. In M. ZANNA (Ed.), Advances in Experimental Social Psychology, 25, 1-65. Orlando, FL: Academic Press. 
Schwartz, S. H., \& BiLSKy, W. (1987). Toward a universal psychological structure of human values. Journal of Personality and Social Psychology, 53(3), 550-562.

SIMS, R. L. (1993). The relationship between academic dishonesty and unethical business practices. Journal of Education for Business, 68(12), 207-211.

Shaftel, J., \& ShAFTEL, T. L. (2005). The influence of effective teaching in accounting on student attitudes, behavior, and performance. Issues in Accounting Education, 20(3), 231-246.

Stuber-McEwen, D., Wiseley, P., Hoggatt, S. (2009) Point, click, and cheat: Frequency and type of academic dishonesty in the virtual classroom. Online Journal of Distance Learning Administration, (12)3.

TANG, T. L. \& CHEN, Y. (20o8). Intelligence vs. wisdom: The love of money, Machiavellianism, and unethical behavior across college major and gender. Journal of Business Ethics, 82(1), 1-26.

Teixeira, A. A. C. (2013). Sanding the wheels of growth: Cheating by economics and business students and 'real world' corruption. Journal of Academic Ethics, 11, 269-274.

\section{Tables}

Table 1

Schwartz's 57 Single Values

\begin{tabular}{|l|l|}
\hline Value Type & Single Values \\
\hline Universalism & $\begin{array}{l}\text { broadminded, wisdom, social justice, equality, a world at peace, a world of beauty, } \\
\text { unity with nature, protecting the environment }\end{array}$ \\
\hline Self-direction & creativity, freedom, independent, curious, choosing own goals, self-respect \\
\hline Stimulation & daring, a varied life, an exciting life \\
\hline Hedonism & pleasure, enjoying life, self-indulgent \\
\hline Power & social power, authority, wealth, preserving my public image, social recognition \\
\hline Achievement & successful, capable, ambitious, influential, intelligent, \\
\hline Security & $\begin{array}{l}\text { family security, national security, social order, clean, reciprocation of favors, sense of } \\
\text { belonging, healthy }\end{array}$ \\
\hline Tradition & humble, accepting my portion in life, devout, respect for tradition, moderate \\
\hline Conformity & politeness, obedient, self-discipline, honoring of parents and elders \\
\hline Benevolence & helpful, honest, forgiving, loyal, responsible, true friendship, mature love \\
\hline
\end{tabular}

Source: Schwartz (1992, Table IV, p. 28). 
Table 2

Schwartz's Value Types and Their Motivational Goals

\begin{tabular}{|l|l|}
\hline Value Type & Motivational Goal \\
\hline Power & Social status and prestige, control or dominance over people and resources \\
\hline Achievement & Personal success through demonstrating competence according to social standards \\
\hline Hedonism & Pleasure and sensuous gratification for oneself \\
\hline Stimulation & Excitement, novelty, and challenge in life \\
\hline Self-direction & Independent thought and action - choosing, creating, exploring \\
\hline Universalism & $\begin{array}{l}\text { Understanding, appreciation, tolerance, and protection, for the welfare of all people } \\
\text { and for nature }\end{array}$ \\
\hline Benevolence & $\begin{array}{l}\text { Preservation and enhancement of the welfare of people with whom one is in } \\
\text { frequent personal contact }\end{array}$ \\
\hline Tradition & $\begin{array}{l}\text { Respect, commitment, and acceptance of the customs and ideas that traditional } \\
\text { culture and religion provide }\end{array}$ \\
\hline Conformity & $\begin{array}{l}\text { Restraint of actions, inclinations, and impulses likely to upset or harm others and } \\
\text { violate social expectations or norms }\end{array}$ \\
\hline Security & Safety, harmony, and stability of society, of relationships, and of self \\
\hline
\end{tabular}

Source: Adapted from Schwartz (1994, p. 22)

Table 3

Schwartz's Value Types and Their Shared Motivational Goals

\begin{tabular}{|l|l|}
\hline Value Types & Shared Motivational Goal \\
\hline Universalism \& Benevolence & Enhancement of others and transcendence of selfish interests \\
\hline Benevolence \& Tradition & Devotion to one's in-group \\
\hline Benevolence \& Conformity & Normative behavior that promotes close relationships; \\
\hline Conformity \& Tradition & Subordination of self in favor of socially imposed expectations \\
\hline Tradition \& Security & Preserving existing social arrangements that give certainty to life \\
\hline Conformity \& Security & Protection of order and harmony in relations \\
\hline Security \& Power & $\begin{array}{l}\text { Avoiding or overcoming threats by controlling relationships and } \\
\text { resources }\end{array}$ \\
\hline Power \& Achievement & Social superiority and esteem \\
\hline Achievement \& Hedonism & Self-centered satisfaction; \\
\hline Hedonism \& Stimulation & A desire for affectively pleasant arousal \\
\hline Stimulation \& Self-direction & Intrinsic interest in novelty and mastery \\
\hline Self-direction \& Universalism & $\begin{array}{l}\text { Reliance upon one's own judgement and comfort with the } \\
\text { diversity of existence }\end{array}$ \\
\hline
\end{tabular}

Source: Adapted from Schwartz (1994, p. 24-25) 


\section{Figures}

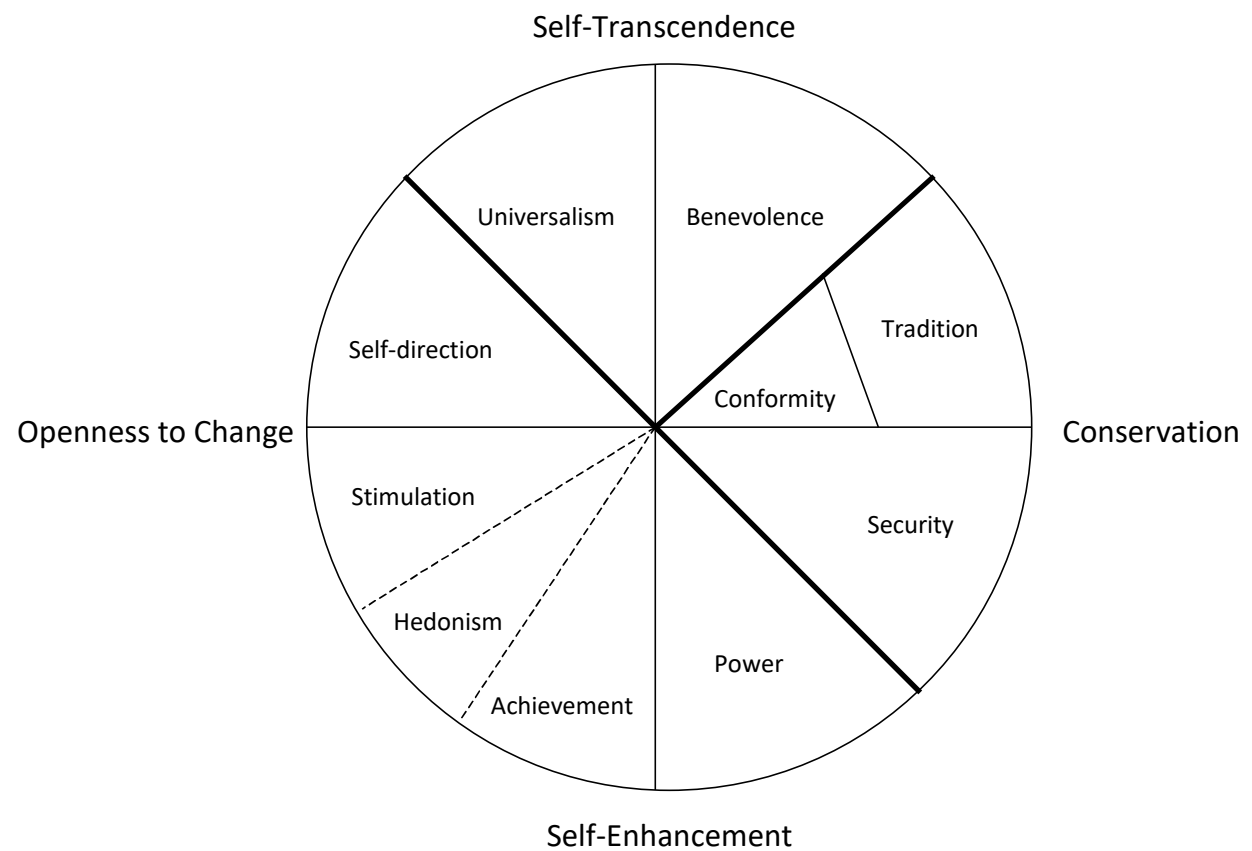

Figure 1. Conceptual framework of Schwartz value types from Schwartz (1994, p. 24)

\section{Appendix A}

\section{Schwartz Value Survey (Schwartz, 1992)}

In this questionnaire you are to ask yourself: "What values are important to ME as guiding principles in MY life, and what values are less important to me?" There are two lists of values on the following pages. These values come from different cultures. In the parentheses following each value is an explanation that may help you to understand its meaning.

Your task is to rate how important each value is for you as a guiding principle in your life. Use the rating scale below:

$\mathrm{o}-$ means the value is not at all important, it is not relevant as a guiding principle for you.

3 - means the value is important.

6 - means the value is very important.

The higher the number $(0,1,2,3,4,5,6)$, the more important the value is as a guiding principle in YOUR life.

-1 is for rating any values opposed to the principles that guide you.

7 is for rating a value of supreme importance as a guiding principle in your life. 
In the space before each value, write the number $(-1,0,1,2,3,4,5,6,7)$ that indicates the importance of that value for you, personally. Try to distinguish as much as possible between the values by using all the numbers. You will, of course, need to use numbers more than once.

Before you begin, read the values in items 1-30 of List I, choose the one that is most important to you and rate its importance. Next, choose the value that is most opposed to your values and rate it 1 . If there is no such value, choose the value least important to you and rate it o or 1 , according to its importance. Then rate the rest of the values in List I.

\begin{tabular}{|l|l|l|l|l|l|l|l|l|}
\hline $\begin{array}{l}\text { opposed to } \\
\text { my values }\end{array}$ & $\begin{array}{l}\text { not } \\
\text { important }\end{array}$ & & important & & & $\begin{array}{l}\text { very } \\
\text { important }\end{array}$ & $\begin{array}{l}\text { of supreme } \\
\text { importance }\end{array}$ \\
\hline-1 & o & 1 & 2 & 3 & 4 & 5 & 6 & 7 \\
\hline
\end{tabular}

1 ___ EQUALITY (equal opportunity for all)

2 INNER HARMONY (at peace with myself)

3 SOCIAL POWER (control over others, dominance)

4 PLEASURE (gratification of desires)

5 _ FREEDOM (freedom of action and thought)

6 _ A SPIRITUAL LIFE (emphasis on spiritual not material matters)

7 SENSE OF BELONGING (feeling that others care about me)

8 __ SOCIAL ORDER (stability of society)

9 __ AN EXCITING LIFE (stimulating experiences)

10 _ MEANING IN LIFE (a purpose in life)

11 ___ POLITENESS (courtesy, good manners)

12 WEALTH (material possessions, money)

13 _ NATIONAL SECURITY (protection of my nation from enemies)

14 SELF RESPECT (belief in one's own worth)

15 _ RECIPROCATION OF FAVOURS (avoidance of indebtedness)

16 _ CREATIVITY (uniqueness, imagination)

17 A W WORLD AT PEACE (free of war and conflict)

18 RESPECT FOR TRADITION (preservation of timehonoured customs)

19 _ MATURE LOVE (deep emotional \& spiritual intimacy)

20 __ SELFDISCIPLINE (selfrestraint, resistance to temptation)

21 _ PRIVACY (the right to have a private sphere)

22 _ FAMILY SECURITY (safety for loved ones)

23 SOCIAL RECOGNITION (respect, approval by others)

24 UNITY WITH NATURE (fitting into nature)

25 _ A VARIED LIFE (filled with challenge, novelty and change)

26 WISDOM (a mature understanding of life) 
27 _ AUTHORITY (the right to lead or command)

28 _ TRUE FRIENDSHIP (close, supportive friends)

29 _ A WORLD OF BEAUTY (beauty of nature and the arts)

30 ___ SOCIAL JUSTICE (correcting injustice, care for the weak)

\section{VALUES LIST II}

Now rate how important each of the following values in items $31-57$ is for you as a guiding principle in YOUR life. These values are phrased as ways of acting that may be more or less important for you. Once again, try to distinguish as much as possible between the values by using all the numbers.

Before you begin, read the values in List II, choose the one that is most important to you and rate its importance. Next, choose the value that is most opposed to your values, or - if there is no such value - choose the value least important to you, and rate it $-1,0$, or 1 , according to its importance. Then rate the rest of the values.

AS A GUIDING PRINCIPLE IN MY LIFE, this value is:

\begin{tabular}{|l|l|l|l|l|l|l|l|l|}
\hline $\begin{array}{l}\text { opposed to } \\
\text { my values }\end{array}$ & $\begin{array}{l}\text { not } \\
\text { important }\end{array}$ & & important & & & $\begin{array}{l}\text { very } \\
\text { important }\end{array}$ & $\begin{array}{l}\text { of supreme } \\
\text { importance }\end{array}$ \\
\hline-1 & o & 1 & 2 & 3 & 4 & 5 & 6 & 7 \\
\hline
\end{tabular}

31 INDEPENDENT (selfreliant, selfsufficient)

32 _ MODERATE (avoiding extremes of feeling \& action)

33 _ LOYAL (faithful to my friends, group)

34 _ AMBITIOUS (hardworking, aspiring)

35 _ BROADMINDED (tolerant of different ideas and beliefs)

36 _ HUMBLE (modest, selfeffacing)

37 _ DARING (seeking adventure, risk)

38 __ PROTECTING THE ENVIRONMENT (preserving nature)

39 _ INFLUENTIAL (having an impact on people and events)

40 __ HONOURING OF PARENTS AND ELDERS (showing respect)

41 _ CHOOSING OWN GOALS (selecting own purposes)

42 _ HEALTHY (not being sick physically or mentally)

43 CAPABLE (competent, effective, efficient)

44 ACCEPTING MY PORTION IN LIFE (submitting to life's circumstances)

45 _ HONEST (genuine, sincere)

46 _ PRESERVING MY PUBLIC IMAGE (protecting my "face”)

47 OBEDIENT (dutiful, meeting obligations)

48 _ INTELLIGENT (logical, thinking)

49 HELPFUL (working for the welfare of others)

50 __ ENJOYING LIFE (enjoying food, sex, leisure, etc.) 
51 __ DEVOUT (holding to religious faith \& belief)

52 _ RESPONSIBLE (dependable, reliable)

53 CURIOUS (interested in everything, exploring)

54 FORGIVING (willing to pardon others)

55 __ SUCCESSFUL (achieving goals)

56 CLEAN (neat, tidy)

57 _ SELF-INDULGENT (doing pleasant things)

\section{Author}

Caroline Josephine Burns, Saint Mary's College of California, 1928 St Marys Rd 94556, Moraga, USA; e-mail: cburns@stmarys-ca.edu 